\title{
ETL
}

International Conference on Research in Education, Teaching and Learning

Paris, France| November 2 -4, 2018

\section{Variability of the Perception of Dropping Out Of Czech Higher Education System}

\author{
Martin KALEJA Silesian University in Opava/ Research Centre for Social Inclusion \\ Bezrucovo nam. 14, 74601 Opava, Czech Republic
}

\begin{abstract}
The paper focuses on some current issue of higher education system in the Czech Republic. It presents the key results of mixed designed research. The main aim of the article is giving an interpretation and an explanation of existing problem in the higher education system, occurring not only in the Czech Republic. It brings a few of the perspectives of being unsuccessful student in the higher education. The view from both the selected university, and some students who are unsuccessful, is a part of the presented text. We dealt also with the perspectives of both the students' teachers and parents in our research.
\end{abstract}

Keywords: higher education, dropping out, unsuccessful student, research, perspectives 
